Karolina Kotulewicz

Katedra Nauk Politycznych

Uniwersytet Ekonomiczny w Krakowie

\title{
Koncepcje ustroju politycznego i ekonomiczno-społecznego Polskiego Stronnictwa Ludowego w latach 1989-2011
}

\section{Streszczenie}

Artykuł przedstawia ewolucję myśli politycznej Polskiego Stronnictwa Ludowego po 1989 r. do wyborów parlamentarnych w 2011 r. Główne problemy, jakie poruszono, to koncepcja ustroju politycznego państwa oraz modelu gospodarczego i polityki socjalnej. Wpływ na koncepcje programowe PSL mają wieloletnie tradycje tej partii oraz wyznawane wartości, wśród których ważne miejsce zajmują wartości rodzinne i religijne. Działalność partii odznacza się aktywnością nie tylko na poziomie organu władzy ustawodawczej, ale i w ramach organu władzy wykonawczej, poprzez tworzenie rządów koalicyjnych.

Słowa kluczowe: Polskie Stronnictwo Ludowe, myśl polityczna, ustrój polityczny państwa, model gospodarczy, polityka społeczna.

\section{Wprowadzenie}

Polskie Stronnictwo Ludowe jest jednym z najstarszych ugrupowań politycznych, które po 1989 r. aktywnie włączyło się w proces przemian ustrojowych, gospodarczych i społecznych. Na szczególną uwagę w związku z działalnością tej partii zasługuje fakt, że od 1991 r. znajduje się ona w składzie wszystkich parla- 
mentów i w znaczący sposób wpływa na polską politykę. PSL zawierało koalicje rządowe z Sojuszem Lewicy Demokratycznej (lata 1993-1997 oraz 2001-2003) i z Platformą Obywatelską (lata 2007-2011, okres od listopada 2011 r. do chwili obecnej). W. Pawlak, ówczesny lider ruchu ludowego, dwukrotnie pełnił funkcję premiera (od 5 czerwca do 2 lipca 1992 r. oraz od 8 listopada 1993 r. do 1 czerwca 1995 r.). Polskie Stronnictwo Ludowe miało swoich przedstawicieli w rządach T. Mazowieckiego, J.K. Bieleckiego, J. Olszewskiego, J. Oleksego, W. Cimoszewicza, L. Millera i D. Tuska. Ponadto działacze tej partii kilkakrotnie pełnili funkcje marszałków sejmu i senatu oraz obsadzali inne wysokie stanowiska państwowe [Danel 2010, s. 43].

PSL jest ugrupowaniem politycznym, które samo siebie zalicza do partii centrowych. W centrum sceny politycznej partię tę sytuuje stosunek do tradycji, opowiadanie się za wartościami chrześcijańskimi i narodowymi, umiarkowanie i tolerancja. Pod względem koncepcji społecznych PSL jest bliżej natomiast do ugrupowań socjaldemokratycznych. Taka pozycja pozwala Polskiemu Stronnictwu Ludowemu na współpracę i tworzenie koalicji z umiarkowanymi siłami politycznymi zarówno z prawej, jak i z lewej strony sceny politycznej - pod warunkiem, że może ono liczyć na partnerstwo i możliwość realizowania przynajmniej w części swojego programu. PSL nie tylko zachowuje dystans, ale stara się przeciwstawiać - jak twierdzą wiodący działacze partii - wszelkim postawom skrajnym, niezależnie od tego, czy wywodzą się one z lewicy, czy z prawicy. PSL stoi bowiem na stanowisku, że Polsce potrzebne jest umiarkowane centrum społeczne mogące skutecznie przeciwdziałać szkodliwej w skutkach walce dwóch przeciwstawnych obozów politycznych [Nie interesuje nas... 1998].

Polskie Stronnictwo Ludowe jest stabilnym przedstawicielem ruchu ludowego w Polsce po 1989 r., które ma własne koncepcje ustroju politycznego państwa oraz jego modelu gospodarczego i polityki społecznej. W artykule podjęto próbę nakreślenia propozycji wysuwanych w tym zakresie przez PSL po 1989 r. aż do ostatnich wyborów parlamentarnych w 2011 r., a jako podstawę badawczą przyjęto dokumenty programowe ugrupowania.

\section{Koncepcja ustroju politycznego państwa}

Od początku transformacji w Polsce PSL w swych programach politycznych i społeczno-gospodarczych akcentowało, że zachodzące zmiany powinny zmierzać do umocnienia demokratycznego systemu sprawowania władzy, a mechanizm przebudowy ustrojowej pojmowało jako proces kształtowania demokracji politycznej, gospodarczej i społecznej. Dla tej partii demokratyzacja oznaczała proces obejmujący różne wzajemnie się warunkujące formy, stąd też po 1989 r. 
PSL niejednokrotnie zaznaczało, że demokracja polityczna nie jest pełna, jeśli równolegle nie zachodzi proces demokratyzacji gospodarczej i społecznej. Jednocześnie podkreślało, że demokratyzację gospodarczą i społeczną może ograniczać niedostatek demokracji politycznej. W ten sposób PSL próbowało pokazać, że odróżnia się od ugrupowań skrajnie liberalnych i prawicowych, które traktują demokrację wyłącznie w kategoriach politycznych [Żywia, bronia, gospodaruja... 1993, s. 12]. Tuż po wyborach do sejmu kontraktowego klub parlamentarny PSL $\mathrm{z}$ wielkim zaangażowaniem włączył się $\mathrm{w}$ prace nad nową konstytucją. W poprzedzającej wybory parlamentarne kampanii kandydaci z ramienia PSL deklarowali, że uchwalenie konstytucji będzie najważniejszym zadaniem nowo wybranych władz [Pastuszka i Machynia 1997, s. 2].

Opracowany przez PSL projekt konstytucji uwzględniał zasady, jakimi kieruje się ruch ludowy, czyli [Pastuszka i Machynia 1997, s. 5]:

- uznanie naturalnych i niezbywalnych praw każdego człowieka do życia, wolności, godności i podmiotowości w życiu społecznym,

- uznanie zasad etyki chrześcijańskiej i humanizmu chrześcijańskiego jako trwałej podstawy kształtowania norm życia państwowego i międzynarodowego,

- uznanie wiary w przydatność każdego człowieka dla społeczeństwa,

- uznanie wielowiekowych dążeń chłopów do życia w wolności i równoprawnego udziału w życiu państwowym, do godnego bytu i rozwoju,

- uznanie ducha patriotyzmu, umiłowania ojczyzny, współodpowiedzialności za nią i poświęcenia dla niej,

- uznanie prawdy, że „w chłopie żyje i odradza się naród”,

- uznanie wiary chłopów, że ojczyzna tworzona i wspierana przez nich sprawiedliwie odwzajemnia się im troską, czyniąc każdego z nich swoim współgospodarzem,

- uznanie przekonania, że suwerenna Polska winna zapewnić sprawiedliwość społeczną i równouprawnienie wszystkich obywateli.

Projekt konstytucji PSL przewidywał parlamentarno-gabinetowy system rządów z silną pozycją premiera. Jednocześnie zakładał, że jedynym źródłem władzy państwowej jest naród wyrażający swoją wolę w wolnych wyborach, a w szczególnych przypadkach w formie referendum [Pastuszka i Machynia 1997, s. 5].

Zamysłem tego projektu była równowaga władz [Jachymek 1993, s. 40]. Z jego treści wynikało, że najwyższa władza w państwie powinna należeć do sejmu, liczącego 460 posłów i będącego politycznym przedstawicielstwem narodu, wyłonionego w wyborach powszechnych, równych, bezpośrednich, proporcjonalnych, w głosowaniu tajnym [Żywia, bronia, gospodaruja... 1993, s. 14]. Projekt konstytucji PSL był wzbogacony o koncepcję senatu jako wyższej izby samorządowej (art. 41 i 42) [Konstytucja RP. Projekt... 1990]. W skład senatu wchodziłoby 100 senatorów będących przedstawicielami samorządów: terytorialnego, gospo- 
darczego i zawodowego, a także reprezentanci organizacji wyższej użyteczności publicznej, takich jak towarzystwa naukowe czy kulturalne (art. 49) [Konstytucja RP. Projekt... 1990]. Izba ta miałaby koordynować działalność różnych organów samorządu, a zakres jej prac obejmowałby całokształt spraw gospodarczych i szeroko rozumianej polityki kulturalno-społecznej państwa, czyli oświaty, kultury, zdrowia itp. Tak skonstruowany senat byłby ustrojową płaszczyzną konsultowania z zainteresowanymi środowiskami projektów ustaw uchwalonych przez sejm.

Propozycja PSL dotycząca utworzenia senatu w postaci izby samorządowej wiązała się z chęcią wzmocnienia pozycji samorządu w stosunku do władzy centralnej. Partia ta wychodziła z założenia, że izba samorządowa mogłaby zagospodarować przestrzeń między władzą a społeczeństwem, co sprzyjałoby utożsamianiu się obywateli z własnym państwem oraz usprawniłoby przebieg procesu transformacji ustrojowej, ponieważ izba pomagałaby w rozstrzyganiu istotnych z punktu widzenia społeczeństwa problemów [Pastuszka i Machynia 1997, s. 6].

Z tego względu PSL uznało, że izba samorządowa powinna mieć nie tylko prawo do inicjatywy ustawodawczej, ale także uprawnienia kontrolne w stosunku do rządu, realizowane w podobnych formach jak te przysługujące sejmowi. Izba miałaby prawo składania zapytań i interpelacji, prawo żądania informacji oraz występowania z wotum nieufności dla rządu. Projekt PSL zakładał, że senat powinien współuczestniczyć w powoływaniu i odwoływaniu osób na niektóre ważne stanowiska. Dotyczyć to miałoby takich instytucji, jak: Rzecznik Praw Obywatelskich, Trybunał Konstytucyjny, Trybunał Stanu czy prezes Najwyższej Izby Kontroli [Pastuszka i Machynia 1997, s. 7].

Zgodnie z projektem konstytucji PSL senat powinien mieć prawo weta w sprawach związanych z ustawodawstwem dotyczącym działalności różnych organów samorządu. Chodziło tu szczególnie o takie sprawy, jak: ustawa o samorządzie terytorialnym, ordynacja wyborcza do samorządu terytorialnego, stanowienie przepisów prawa miejscowego, prawa w regionalnych izbach gospodarczych, lekarskich itp. oraz dokonywanie zmian na mapie administracyjnej kraju. Należy podkreślić, że druga izba parlamentu byłaby ciałem w pełni autonomicznym i apolitycznym. Pozycja prawna jej członków byłaby analogiczna jak posłów na sejm, z tym że senatorowie nie mogliby tworzyć klubów politycznych, a jedynie społeczno-zawodowe [Pastuszka i Machynia 1997, s. 7].

Projekt konstytucji PSL wprowadzał także mechanizmy zabezpieczające przed nadużyciami władzy, chronił prawa i wolności obywateli, przedstawiał wizję państwa socjalnego. Koncepcja ta bazowała na trójpodziale władzy. Władza wykonawcza miałaby dualistyczny charakter i należałaby do prezydenta, wybieranego w wyborach powszechnych, i rządu, wybieranego przez sejm. Według PSL w stosunkach wewnętrznych i międzynarodowych prezydent jest najwyższym 
przedstawicielem państwa, a wybierany przez cały naród stanowi symbol jedności (art. 55). Co do kadencyjności urzędu prezydenta, to w projekcie konstytucji w art. 56 wariancie II PSL zaproponowało 6 lat. W ten sposób kadencja prezydenta nie byłaby zsynchronizowana z 4-letnią kadencją sejmu. Założenie to było jednak nieuzasadnione, ponieważ nigdzie w projekcie nie ma przepisu o długości kadencji sejmu i izby samorządowej [Wierzbowski 1990]. Rząd z kolei byłby naczelnym wykonawczym i zarządzającym organem władzy i administracji państwowej (art. 60) [Konstytucja RP. Projekt... 1990]. Koncepcje PSL dotyczące izby samorządowej i kadencji prezydenta nie uzyskały aprobaty Komisji Konstytucyjnej.

Z uwagi na fakt, że PSL jest ugrupowaniem przywiązanym do chrześcijańskiej religii i tradycji, dążyło ono do tego, by nowa konstytucja RP odzwierciedlała ducha narodu polskiego i odpowiadała demokratycznym standardom. Rola partii uwidoczniła się szczególnie w czasie dyskusji nad preambułą i artykułami określającymi stosunki między Rzeczpospolitą a Kościołem i związkami wyznaniowymi. W czasie debaty w Komisji Konstytucyjnej PSL opowiadało się za tym, by preambuła zawierała wezwanie do Boga. Szukało takiej formuły, która odpowiadałaby wszystkim Polakom i łączyła ich, czyli zawierała odwołanie do narodu polskiego, Boga, chrześcijańskich tradycji oraz demokratycznych i niepodległościowych dążeń Polaków [Pastuszka i Machynia 1997, s. 7].

Na uwagę zasługuje wkład PSL w określeniu w konstytucji RP miejsca Kościoła katolickiego oraz innych kościołów i wyznań religijnych w życiu państwa oraz zapewnienie prawa do nauczania religii w szkole i prawa rodziców do wychowywania dzieci zgodnie z własnymi przekonaniami. Przedstawiciele PSL zgłosili propozycję przepisu konstytucyjnego, na podstawie którego stosunki państwo-Kościół katolicki określa konkordat i ustawy. PSL optowało za tym, by konstytucja uwzględniała światopoglądy wierzących i niewierzących, oraz zaproponowało, żeby nie umieszczać w ustawie zasadniczej zapisów określających charakter państwa. Według PSL państwo nie powinno mieć prawa do ateizacji, a Kościół nie powinien mieć prawa do urzędowej klerykalizacji życia publicznego [Pastuszka i Machynia 1997, s. 6].

Drogą kompromisu w obecnie obowiązującej Konstytucji przyjęto następujący zapis art. 25 [Konstytucja Rzeczypospolitej Polskiej z dnia 2 kwietnia 1997 r. ...]:

„1. Kościoły i inne związki wyznaniowe są równouprawnione.

2. Władze publiczne w Rzeczypospolitej Polskiej zachowują bezstronność w sprawach przekonań religijnych, światopoglądowych i filozoficznych, zapewniając swobodę ich wyrażania w życiu publicznym.

3. Stosunki między państwem a kościołami i innymi związkami wyznaniowymi są kształtowane na zasadach poszanowania ich autonomii oraz wzajemnej niezależności każdego w swoim zakresie, jak również współdziałania dla dobra człowieka i dobra wspólnego. 
4. Stosunki między Rzeczpospolitą Polską a Kościołem katolickim określają umowa międzynarodowa zawarta ze Stolicą Apostolską i ustawy.

5. Stosunki między Rzeczpospolitą Polską a innymi kościołami oraz związkami wyznaniowymi określają ustawy uchwalone na podstawie umów zawartych przez Radę Ministrów z ich właściwymi przedstawicielami”.

Dzięki uporowi PSL do Konstytucji wprowadzono zapis: „Rodzice mają prawo do zapewnienia dzieciom wychowania i nauczania moralnego i religijnego zgodnie ze swoimi przekonaniami" (art. 53 ust. 3). Cytowany przepis oznacza prawo do nauczania religii w szkołach (prawo, nie obowiązek) - stwarza taką możliwość, gdy życzą sobie tego rodzice lub inni prawni opiekunowie dziecka (por. art. 20 ust. 1 Ustawy z dnia 17 maja 1989 r. o gwarancjach wolności sumienia i wyznania) [Pastuszka i Machynia 1997, s. 11-15; Dudek 1997, s. 126].

Pomimo umieszczenia w treści projektu konstytucji odwołań do Boga PSL opowiadało się za świeckością państwa, co nie oznacza jednak antyreligijności. Równocześnie partia ta podkreślała, że neutralność światopoglądowa instytucji państwowych powinna zapewnić ochronę wolności wyznaniowej wszystkim obywatelom i sprzyjać współpracy wspólnot religijnych z władzami państwowymi oraz poszanowaniu ich autonomii [Żywia, bronia, gospodarują... 1993, s. 16].

Senatorowie PSL delegowani do Komisji Konstytucyjnej, świadomi słów W. Witosa ,tyle ojczyzny, ile ziemi”, walczyli o wprowadzenie do ustawy zasadniczej przepisu, zgodnie z którym „podstawą ustroju rolnego państwa jest gospodarstwo rodzinne" (art. 23). Zapis ten jest wyrazem spełnienia dążeń ruchu ludowego obecnych w ideach agraryzmu i społecznej nauce Kościoła [Pastuszka i Machynia 1997, s. 11-15].

Reprezentantów PSL w Zgromadzeniu Narodowym satysfakcjonowały przepisy o prawie do własności zawarte w Konstytucji Rzeczypospolitej Polskiej z dnia 2 kwietnia 1997 r.: „Rzeczpospolita Polska chroni własność i prawo dziedziczenia” (art. 21 ust. 1), „Każdy ma prawo do własności, innych praw majątkowych oraz prawo dziedziczenia”, „Własność może być ograniczona tylko w drodze ustawy i tylko w zakresie, w jakim nie narusza istoty prawa własności" (art. 64 ust. 1 i 3). Przepisy te oznaczają, że prawo do ograniczenia własności prywatnej należy wyłącznie do sejmu i senatu. Wprawdzie dopuszcza się pewną formę wywłaszczenia, ale ,jedynie wówczas, gdy jest [ono] dokonywane na cele publiczne i za słusznym odszkodowaniem" (art. 21 ust. 2). Takim celem publicznym może być budowa drogi, linii kolejowej itp. Tym samym, jak twierdziło PSL, treść wymienionych wyżej artykułów ustawy zasadniczej nie pozostawia pola na żadne próby zmian w kwestii własności [Pastuszka i Machynia 1997, s. 9-10].

W kwestii podstaw ustroju gospodarczego Polski PSL było za wprowadzeniem do Konstytucji przepisu o społecznej gospodarce rynkowej opartej na prywatnej własności i wolności działalności gospodarczej, a także solidarności, 
dialogu i współpracy partnerów społecznych. Zabezpieczyłoby to pracowników przed wyzyskiwaniem, a praca nie uprzedmiotawiałaby człowieka [Pastuszka i Machynia 1997, s. 10].

PSL udało się wprowadzić do Konstytucji przepisy gwarantujące bezpłatną naukę we wszystkich szkołach publicznych (państwowych i samorządowych) na wszystkich poziomach kształcenia (również na studiach wyższych). Art. 70. ustawy zasadniczej ma duże znaczenie dla edukacji młodych pokoleń Polaków, szczególnie dzieci chłopskich. Według PSL przepis ten umożliwia wyrównywanie szans edukacyjnych mieszkańcom wsi i małych miasteczek oraz pomaga usuwać dysproporcje oświatowe między miastem a wsią [Pastuszka i Machynia 1997, s. 15-16].

Projekt konstytucji PSL zakładał decentralizację władzy, precyzyjnie regulując niektóre ważne kwestie samorządowe. Partia bardzo wspierała rozwój samorządności lokalnej, ponieważ uznawała ją za podstawę ustroju demokratycznego w Polsce. W związku z tym spory między samorządem a zarządem gminy powinien rozstrzygać Naczelny Sąd Administracyjny. Projekt dopuszczał możliwość stanowienia przez samorządy prawa lokalnego (pod warunkiem zgodności z obowiązującymi ustawami) oraz wydawania rozporządzeń [Pastuszka i Machynia 1997, s. 6].

PSL traktowało samorząd terytorialny jako podstawę administracji państwowej, wyraz demokratycznego ustroju państwa oraz szkołę wychowywania obywatelskiego [Jachymek 1993, s. 40]. Należy pamiętać, że w trakcie prac nad reformą administracyjno-terytorialną Polskie Stronnictwo Ludowe nie popierało zgłaszanej propozycji zmniejszenia liczby województw i było przeciwne tworzeniu powiatów, uważając, że zdestabilizuje to życie społeczne i polityczne, a także wiązać się będzie z dodatkowymi kosztami. Działacze partii niejednokrotnie podkreślali, że utworzenie powiatów jest marnotrawieniem środków publicznych na pozorowane działania [Żywia, bronia, gospodarują... 1993, s. 18].

PSL opowiadało się za przestrzeganiem zasady niezależności sądownictwa, równości obywateli wobec prawa i konieczności jego bezwzględnego przestrzegania. Sądownictwo ma być gwarantem właściwego funkcjonowania wymiaru sprawiedliwości, a niezawisłość sądu musi być gwarantowana konstytucyjnie. Wymiar sprawiedliwości powinien być sprawowany przez Sąd Najwyższy, sądy powszechne i sądy wojskowe. PSL popierało wprowadzenie ławników pochodzących z wyborów, którzy wpływaliby nie tylko na wydawanie sprawiedliwych wyroków, ale także pełniliby wobec ludności rolę doradców i wychowawców. Ponadto ugrupowanie było przeciwne karze śmierci i wyrażało swój sprzeciw wobec wprowadzenia stosownej zmiany w treści ówcześnie obowiązującej konstytucji [Jachymek 1993, s. 41-42]. 
W 2007 r. po wyborach parlamentarnych PSL weszło w skład rządu koalicyjnego utworzonego przez Platformę Obywatelską, która rozpoczęła na nowo dyskusję dotyczącą kompetencji i wzajemnych relacji prezydenta i premiera. Według PSL sprowadzenie funkcji prezydenta do wyłącznie reprezentacyjnej nie jest zasadne, zwłaszcza że autorytet osoby pełniącej ten urząd wynika ze społecznego mandatu zaufania wyrażonego w wyborach powszechnych. Partia uważała, że prezydent ma być strażnikiem Konstytucji, a także uczestnikiem procesu stanowienia prawa. $Z$ tego względu powinien on mieć prawo wnoszenia poprawek do projektów ustaw. Równocześnie zaproponowano ograniczenie mu prawa weta. Wyłącznie rządowi mogłyby przysługiwać z kolei kompetencje w zakresie polityki obronnej i zagranicznej. Prezydent mógłby za to powoływać prokuratora generalnego [Hurkała 2009].

Polskie Stronnictwo Ludowe wyraziło także sprzeciw wobec propozycji PO dotyczącej zmniejszenia liczby posłów na sejm z 460 do 300 oraz liczby senatorów ze 100 do 39 [ProPOzycje pod sondaże... 2010]. W odpowiedzi wysunęło propozycję zmiany usytuowania senatu w ustroju politycznym i prawnym. Zaproponowało, by stał się on izbą samorządową, składającą się z przedstawicieli samorządów terytorialnych, organizacji pracodawców i pracowników, samorządu zawodowego oraz środowisk naukowych. Do kompetencji izby należałby wybór prezesa NIK i Rzecznika Praw Obywatelskich. Najważniejszym celem zmian powinno być bowiem wzmocnienie demokracji, a nie jej ograniczenie. W rzeczywistości dla kosztów utrzymania parlamentu większe znaczenie mają wydatki stałe na budynki, kancelarie prawne czy służby techniczne niż te związane bezpośrednio z parlamentarzystami. Ważne jest też, by sejm był reprezentatywny, czyli by zasiadali w nim przedstawiciele nawet niewielkich grup, ale o różnych poglądach i interesach [Hurkała 2009].

\section{Model gospodarki i polityki społecznej państwa}

Polskie Stronnictwo Ludowe od początku przemian ustrojowych opowiadało się za przekształceniem nieefektywnego systemu gospodarki centralnie planowanej w model społecznej gospodarki rynkowej skutecznie zaspokajający potrzeby obywateli. W kwestii zmian gospodarczych sprzeciwiało się „szokowej terapii”, a zwłaszcza szybkiemu otwarciu polskiego rynku dla silniejszych ekonomicznie i konkurencyjnych przedsiębiorstw zagranicznych, ponieważ uważało, że może to przyczynić się do licznych bankructw polskich wytwórców. Sprzeciwiało się również liberalnej koncepcji „państwa minimum” - państwa ograniczonego do wypełniania roli „żandarma” i „stróża nocnego” - a więc popierało gospodarkę rynkową z poszerzonym interwencjonizmem państwowym [Polskie 
partie polityczne... 1996, s. 163]. Najdobitniej o tym świadczą następujące słowa zawarte w programie partii: „Chcieliśmy państwa aktywnego, wspomagającego siły i procesy unowocześniania gospodarki i przekształcania życia społecznego. Państwa realizującego idee społecznej gospodarki rynkowej, prowadzącego aktywną politykę przemysłową, regionalną, społeczną, mającego jasną strategię rozwoju, służącego wszystkim, a nie tylko wybranym grupom społecznym" [Program społeczno-gospodarczy PSL... 2004, s. 3]. PSL było przeciwne szybkiej i nieprzemyślanej prywatyzacji, zwłaszcza prywatyzacji w ramach strategicznych dziedzin gospodarki. W swoich programach podkreślało, że prywatyzacja nie może prowadzić do wywłaszczenia społeczeństwa, a uzyskane w ten sposób środki nie mogą być przeznaczone na cele konsumpcyjne. Według PSL prywatyzacja ma pobudzać rozwój gospodarczy, a nie przynosić straty i pomniejszać dochody państwa [Żywia, bronia, gospodaruja... 1993, s. 22]. Z kolei prywatyzacja sektora rolnego ma służyć poprawie infrastruktury obszarowej gospodarstw rolnych [Program polityczny i społeczno-gospodarczy... 1991, s. 7]. Partia krytycznie odnosiła się do tworzenia Narodowych Funduszy Inwestycyjnych (NFI), a swoje koncepcje i propozycje prezentowała w kolejnych programach, za każdym razem podkreślając, że podczas transformowania polskiej gospodarki popełniono wiele błędów, których można było uniknąć, gdyby postulaty PSL zostały uwzględnione [Program spoteczno-gospodarczy PSL... 2004].

We wszystkich dokumentach programowych PSL poświęconych problematyce społeczno-gospodarczej prezentowany był pogląd, że wprowadzenie gospodarki rynkowej nie oznacza rezygnacji z zasad sprawiedliwości społecznej, dążenie do której uważa się za fundamentalny element polityki gospodarczej państwa [Program polityczny i społeczno-gospodarczy... 1991, s. 7]. Państwo powinno odgrywać aktywną rolę w zakresie ograniczania do niezbędnego minimum ujemnych skutków przemian gospodarczych.

PSL było zwolennikiem jednakowego traktowania w polityce gospodarczej państwa wszystkich form własności: prywatnej, państwowej, społecznej, komunalnej i spółdzielczej. Partia ta stała na stanowisku, że czołowym działem wytwórczości powinno być rolnictwo oparte na chłopskich gospodarstwach rodzinnych - najlepiej jej zdaniem użytkujących pracę ludzką. Jednocześnie podkreślała, że liczne kraje osiągnęły dobrobyt dzięki rozwojowi rolnictwa i Polska powinna podążać tą drogą. Przemysł powinien stać się drugim obszarem wytwórczości narodowej, przy czym spośród różnych gałęzi to przemysł rolno-spożywczy powinien zajmować wiodącą pozycję [Jachymek 1993, s. 32]. Spó1dzielczość powinna natomiast wypełniać lukę między rolnictwem a przemysłem i być rozwijana w różnych formach: rolniczej, handlowej, wytwórczej, mieszkaniowej, finansowej itp. Jest to zgodne z głoszonym przez partię poglądem, gdyż taka forma uspołecznienia przedsiębiorstw i organizacji umożliwiałaby lepszą 
kontrolę ich działalności i pozwalała wywierać na nie bezpośredni wpływ [Jachymek 1993, s. 32-33].

W kwestii dochodów państwa PSL zajęło stanowisko, że powstaje on z podatków od osób fizycznych i prawnych, z zaciąganych przez rząd kredytów oraz z innych źródeł. Według partii celem działalności gospodarczej państwa powinno być tworzenie podstaw wzrostu zamożności i poprawy warunków socjalno-bytowych i kulturalnych społeczeństwa, a krótko- i średnioterminowe cele gospodarcze nie mogą dominować nad długofalową racją stanu państwa i polskiego społeczeństwa [Jachymek 1993, s. 33-34].

Dla PSL ważny był także rozwój małej i średniej przedsiębiorczości. Ugrupowanie podjęło działania na rzecz odbiurokratyzowania i uproszczenia przepisów prawnych dotyczących prowadzenia działalności gospodarczej. Szczególną wagę PSL przywiązywał do precyzji i jednoznaczności przepisów podatkowych oraz różnych prawnych uregulowań finansowych eliminujących dowolność interpretacji przez urzędników. Partia ta zwróciła uwagę na szereg problemów związanych z kredytowaniem działalności gospodarczej małych i średnich przedsiębiorstw oraz podkreślała, że należy wyeliminować patologie w funkcjonowaniu firm z kapitałem zagranicznym, które dopuszczają się nieuzasadnionego transferu dochodów za granicę [Program społeczno-gospodarczy... 2001].

PSL sprzeciwiało się reformom zapoczątkowanym przez rząd AWS-UP w zakresie polityki podatkowej, wyrażając pogląd, że powinna być zastosowana jednolita stawka podatkowa dla wszelkiej działalności gospodarczej bez względu na jej rozmiary. Sprzeciwiało się również wprowadzeniu podatku liniowego oraz podwyżce VAT, popierało obniżenie stawki VAT z 22\% do 16\% [Program społeczno-gospodarczy... 2001]. W kampanii wyborczej do parlamentu w 2005 r. ugrupowanie dążyło do obniżenia kosztów kredytów dla przedsiębiorców, opowiadało się także za zwiększeniem ich dostępności [Deklaracja wyborcza... 2005, s. 7]. PSL było przeciwne wprowadzeniu podatku katastralnego, ponieważ uważało, że zagraża to zachowaniu własności domów i mieszkań przez dotychczasowych właścicieli [Deklaracja wyborcza... 2005, s. 12].

Partia we wszystkich swoich programach oraz deklaracjach opowiadała się za stabilnym i zrównoważonym rozwojem gospodarczym, a za główne narzędzie służące realizacji tego celu uznawała wspieranie rozwoju przedsiębiorczości. W sytuacji niestabilności finansów światowych PSL optowało za zachowaniem dużej czujności oraz umiejętnym i szybkim reagowaniem w celu utrzymania równowagi finansów krajowych. W związku z powyższym PSL opowiadało się m.in. za: racjonalizacją wydatków publicznych, zwiększeniem ściągalności podatkowej, wprowadzeniem systemu ulg podatkowych, wspieraniem aktywności i innowacyjności polskich przedsiębiorstw, modernizacją dróg krajowych 
i transportu, a także zwiększeniem dochodów własnych samorządów gminnych [Człowiek jest najważniejszy... 2011, s. 12-14].

W zakresie polityki społecznej PSL opowiadało się za upodmiotowieniem człowieka - prowadzona przez państwo polityka podatkowa powinna służyć jego dobru. Aby nie dopuścić do rozszerzenia obszarów nędzy, PSL postulowało ochronę podstawowych zdobyczy socjalnych zagwarantowanych Konstytucją i ustawami, w szczególności prawa do bezpłatnej opieki lekarskiej i nauki, prawa do niepełnopłatnych lekarstw, przedszkoli, instytucji i placówek kulturalnych itp. Działacze tej partii niejednokrotnie wypowiadali się w kwestii bezrobocia, które ich zdaniem można zmniejszyć, chroniąc istniejące i tworząc nowe miejsca pracy poprzez prowadzenie polityki pełnego i racjonalnego zatrudnienia [Żywią, bronią, gospodaruja... 1993, s. 28-29].

Ponadto PSL opowiadało się za ochroną życia każdej osoby ludzkiej oraz zasad moralności społecznej. Zajmowało wyraźne stanowisko w tej kwestii, głosząc, że prawo każdego człowieka do życia od poczęcia aż do naturalnej śmierci jest nienaruszalne. Zasada ta powinna być zachowana w całym systemie prawnym, a aborcja powinna być ograniczona do ściśle określonych medycznie przypadków: zagrożenia życia matki i dziecka oraz zaawansowanego zniekształcenia płodu. PSL było przeciwne eutanazji, małżeństwom homoseksualnym, adopcji dzieci przez homoseksualistów, klonowaniu ludzi i produkcji żywności genetycznie modyfikowanej [Deklaracja wyborcza... 2005, s. 14].

Polskie Stronnictwo Ludowe uznawało konieczność wspierania rodzin wielodzietnych, macierzyństwa oraz utrzymania niezbędnego poziomu przyrostu naturalnego. W zakresie ubezpieczeń społecznych PSL opowiadało się za jednolitą, gwarantowaną przez państwo emeryturą dla wszystkich ubezpieczonych i rentą opartą na minimum socjalnym. Źródłem ich finansowania byłyby składki opłacane przez pracodawców i dotacje państwa. PSL nie było przeciwne zróżnicowaniu emerytur oraz rent, ale powinno to opierać się na zasadzie dobrowolności i być uzależnione od wysokości indywidualnej składki. Z kolei politykę świadczeń rodzinnych (zasiłki) według partii należy ściśle łączyć z polityką zatrudnienia i polityką demograficzną [Deklaracja wyborcza... 2005, s. 29].

PSL opowiadało się za koniecznością przeprowadzenia reformy ubezpieczeń społecznych i emerytalnych, zaznaczając, że ,reforma emerytalna nie może jednak naruszać nabytych praw osób już ubezpieczonych i prowadzić do ostrych podziałów na emerytów biednych (stary system) i bogatych (nowy system). Państwo nie może dopuścić do nadmiernej deprecjacji emerytur i rent z obecnego systemu w stosunku do wynagrodzeń" [Program społeczno-gospodarczy... 2001]. PSL wiedziało, że wprowadzonej z dniem 1 stycznia 1999 r. reformy ubezpieczeń społecznych nie da się odwrócić, ale było przeciwne obligatoryjnej przynależności osób do 30 roku życia do II filaru prywatnych funduszy emerytalnych, 
stojąc na stanowisku, że wszystkie te osoby muszą mieć zapewnioną swobodę wyboru między ZUS a funduszami emerytalnymi. PSL nie widziało celowości pośredniczenia ZUS w przekazywaniu części składki do prywatnych funduszy emerytalnych, podkreślając, że należy to robić na podstawie umowy cywilnej między pracodawcą, pracownikiem a funduszem emerytalnym. Partia uważała za nieuzasadnione angażowanie się $\mathrm{w}$ ten proces instytucji państwowych. Równocześnie wyrażała pogląd, że składka na fundusz emerytalny jest składnikiem wynagrodzeń osobistych i nałożenie ustawowego obowiązku lokowania jej tylko w prywatnych funduszach jest sprzeczne z Konstytucją [Program społeczno-gospodarczy... 2001]. W kolejnej kampanii wyborczej do parlamentu, w 2005 r., PSL popierało włączenie II filaru systemu emerytalnego do ZUS [Deklaracja wyborcza... 2005, s. 5]. Zaczęło kłaść nacisk na rozwój dobrowolnego systemu ubezpieczeń, tzw. III filaru, początkowo optując za wprowadzeniem bardzo silnej motywacji podatkowej (ulg w podatku dochodowym od osób fizycznych z tytułu wpłat na dodatkowe ubezpieczenia dobrowolne) [Program społeczno-gospodarczy... 2001], żeby potem odstąpić od swego pomysłu na rzecz braku możliwości odliczania składki od kosztów podatkowych [Deklaracja wyborcza... 2005, s. 5]. Polskie Stronnictwo Ludowe opowiadało się jednakże za utrzymaniem w systemie zabezpieczenia socjalnego ZUS i KRUS, wprowadzeniem emerytur pomostowych dla wszystkich grup zawodowych pracujących w trudnych warunkach i zachowaniem możliwości częściowego zatrudnienia w zbliżonych zawodach po osiągnięciu przez pracownika 25-letniego stażu [Deklaracja wyborcza... 2005, s. 5]. Niezależnie od zmian w systemie ubezpieczeń społecznych PSL opowiadało się za uelastycznieniem rynku pracy, czyli: wprowadzeniem zachęt wspomagających aktywność zawodową osób po 50 roku życia, realizacją polityki migracyjnej uwzględniającej potrzeby rynku pracy, rozwojem społeczeństwa obywatelskiego [Dokument X Kongresu PSL... 2008, s. 24].

PSL postulowało utworzenie systemu edukacji narodowej przybliżającego Polskę do rozwiniętych krajów świata. Reformy w systemie oświaty powinny prowadzić do podniesienia poziomu wykształcenia i poszerzenia dostępu obywateli do najnowszych osiągnięć nauki. Partia ta opowiadała się za powszechnym, obowiązkowym i bezpłatnym średnim wykształceniem ogólnokształcącym [Żywia, bronia, gospodaruja... 1993, s. 29-30]. W programie wyborczym z 2001 r. PSL popierała wprowadzenie powszechnego, lecz nieobowiązkowego wychowania przedszkolnego oraz tworzenie zerówek dla 5-latków. W wyborach parlamentarnych w $2001 \mathrm{r}$. ugrupowanie zadeklarowało chęć obniżenia wieku rozpoczęcia obowiązku szkolnego z 7 do 6 lat [Program społeczno-gospodarczy... 2001]. W programie wyborczym z 2011 r. PSL zapowiedziało wprowadzenie systemu bezpłatnego zaopatrywania uczniów szkół podstawowych, gimnazjalnych i średnich w podręczniki i inne pomoce naukowe oraz opracowanie i wdrożenie 
programu bezpłatnego i zdrowego dożywiania dzieci szkolnych [Człowiek jest najważniejszy... 2011, s. 7].

Według PSL celem państwa w zakresie polityki kulturalnej powinno być pomnażanie dorobku kultury narodowej oraz zaspokajanie potrzeb kulturalnych społeczeństwa. Partia ta wspierała sztukę ludową i ruch amatorski. Równocześnie głosiła pogląd, że mecenat nad kulturą, a zwłaszcza ochrona jej zasobów materialnych i sił twórczych, należy do podstawowych obowiązków państwa. Za realizację tego obowiązku odpowiadałyby władze państwowe i samorządowe. Proces urynkowienia kultury państwo wspierałoby tylko tam, gdzie nie szkodziłoby to jej artystycznym i społecznym wartościom [Żywia, bronią, gospodaruja... 1993, s. 30]. Szczególną ochroną powinien być objęty język polski, będący podstawą kultury narodowej [Deklaracja wyborcza... 2005, s. 11].

PSL wyrażało pogląd, że państwo nie może się wycofać z obowiązku tworzenia warunków dla rozwoju ochrony zdrowia i opieki społecznej. Uznawało potrzebę wprowadzenia - ale tylko czasowo - częściowej odpłatności za korzystanie z państwowej służby zdrowia oraz przeznaczenia uzyskanych w ten sposób środków na płace dla pracowników i poprawę wyposażenia szpitali. Partia ta krytycznie odnosiła się do pełnego urynkowienia gospodarki lekami, zwłaszcza w okresie gdy gwałtownie pogarszają się warunki życia dużych grup społecznych [Deklaracja wyborcza... 2005, s. 31]. Po wejściu w życie z dniem 1 stycznia 1999 r. reformy służby zdrowia PSL opowiedziało się za likwidacją kas chorych z uwagi na koszty ich działalności, podkreślając, że zadania te powinny przejąć samorządy szczebla wojewódzkiego. Pobór składek powinien należeć do urzędów skarbowych. Partia podkreślała, że ,prawidłowy przebieg reformy służby zdrowia wymaga jej dofinansowania przez zwiększenie składki na ubezpieczenia zdrowotne z 7,5\% do co najmniej 10\%. Podwyżka składki powinna być zrealizowana etapowo przez ubruttowienie wynagrodzeń" [Program społeczno-gospodarczy... 2001]. W deklaracji wyborczej z 2005 r. PSL zaznaczyło, że system ochrony zdrowia winien mieć charakter powszechnego ubezpieczenia w zakresie koszyka gwarantowanych świadczeń medycznych oraz może się składać z dodatkowych ubezpieczeń - w zakresie ponadstandardowych świadczeń medycznych. PSL było ponadto przeciwne prywatyzacji służby zdrowia, a zwłaszcza szpitali i sanatoriów [Deklaracja wyborcza... 2005, s. 9].

W latach kolejnych w wyniku zaobserwowania negatywnych tendencji w służbie zdrowia PSL zaczęło popierać pomysł wprowadzenia dodatkowych dobrowolnych ubezpieczeń zdrowotnych. Aprobując projekt ustawy o zakładach opieki zdrowotnej, PSL opowiedziało się za częściową komercjalizacją opieki zdrowotnej, wdrożeniem koszyka gwarantowanych świadczeń i podziałem usług na: gwarantowane, częściowo gwarantowane oraz niefinansowane ze środków wspólnych (publicznych) [Dokument X Kongresu PSL... 2008, s. 25]. 


\section{Zakończenie}

Polskie Stronnictwo Ludowe jest partią, która nawiązuje do swoich wieloletnich tradycji. Jest to ugrupowanie o charakterze agrarnym, które od momentu przemian ustrojowych w Polsce uczestnicy w pracach kolejnych parlamentów, a nawet tworzy rządy koalicyjne. Swój program kieruje głównie do mieszkańców wsi. Dla PSL bardzo ważne są wartości rodzinne i religijne.

PSL z dużym zaangażowaniem włączyło się w prace nad tekstem przyjętej w 1997 r. Konstytucji. Jego rola uwidoczniła się szczególnie w czasie dyskusji nad preambułą i artykułami określającymi stosunki między państwem a Kościołem i związkami wyznaniowymi, a także w kwestii zapewnienia prawa do nauczania religii w szkole i prawa rodziców do wychowywania dzieci zgodnie z własnymi przekonaniami.

Polskie Stronnictwo Ludowe opowiadało się za zmianą obecnego charakteru senatu i dążyło do zastąpienia go izbą samorządową, głosząc przy tym pogląd, że pomoże to wzmocnić pozycję samorządów w stosunku do władzy centralnej. PSL postulowało ponadto likwidację powiatów, ponieważ uważało, że ich istnienie stanowi dodatkowe obciążenie dla budżetu państwa. Propozycje te nie znalazły dotychczas uznania, z czego PSL nie kryło niezadowolenia.

Partia opowiadała się za równoważeniem władzy ustawodawczej, wykonawczej i sądowniczej. Popierała niezależność władzy sądowniczej. Nie zgadzała się z propozycjami Platformy Obywatelskiej, które zakładają sprowadzenie funkcji prezydenta do wyłącznie reprezentacyjnej.

W kwestii modelu gospodarczego państwa partia opowiadała się za społeczną gospodarką rynkową, z czym wiąże się poszerzony interwencjonizm państwowy. Według działaczy PSL tylko w taki sposób państwo może skutecznie zaspokajać potrzeby obywateli. PSL popierało także rozwój małej i średniej przedsiębiorczości, czego przykładem jest nie tylko wsparcie propozycji ,,jednego okienka”, ale i optowanie za aktywnością i innowacyjnością polskich przedsiębiorców.

W przypadku polityki społecznej Polskie Stronnictwo Ludowe było zwolennikiem ochrony podstawowych zdobyczy socjalnych, które są zagwarantowane Konstytucją i ustawami, a szczególnie prawa do bezpłatnej opieki zdrowotnej i nauki, prawa do niepełnopłatnych lekarstw, przedszkoli, instytucji i placówek kulturalnych itp. W zakresie problematyki bezrobocia PSL opowiadało się za ochroną istniejących i tworzeniem nowych miejsc pracy poprzez prowadzenie polityki pełnego i racjonalnego zatrudnienia. Ponadto ugrupowanie opowiadało się za istnieniem mieszanego systemu emerytalnego, nie popierało likwidacji KRUS.

Należy podkreślić, że choć nie wszystkie zgłaszane przez Polskie Stronnictwo Ludowe propozycje udało się zrealizować, partia ta wywarła (i nadal wywiera) 
duży wpływ na przebieg reform ustrojowych, gospodarczych i społecznych. Przykładem tego jest aktywność ugrupowania nie tylko w obszarze dyskusji polityczno-społecznych, ale i przy opracowywaniu projektów dokumentów prawnych oraz podczas prac nad nimi.

\section{Literatura}

Człowiek jest najważniejszy. Program wyborczy PSL [2011], Komitet Wyborczy Polskie Stronnictwo Ludowe, Warszawa.

Danel Ł. [2010], Polskie Stronnictwo Ludowe wobec problematyki integracji europejskiej - ewolucja programowa w latach 1991-2009 [w:] Ludowcy i problematyka agrarna na poczatku XXI wieku, red. Ł. Tomczak, Wydawnictwo Marina, Wrocław.

Deklaracja wyborcza Polskiego Stronnictwa Ludowego [2005], Polskie Stronnictwo Ludowe, Warszawa.

Dokumenty X Kongresu PSL [2008], http://www.psl.org.pl/upload/pdf/dokumenty/Dokumenty_X_Kongres_PSL/Psl1.pdf (dostęp: 30.10.2013).

Dudek D. [1997], Konstytucja Rzeczypospolitej Polskiej. Wybór źródeł, Lubelskie Wydawnictwa Prawnicze, Lublin.

Hurkała T. [2009], Zmiany w Konstytucji musza wzmocnić demokracje, ,Zielony Szatndar", 12 grudnia.

Jachymek J. [1993], Neoagraryzm i trzecia droga, Oficyna Wydawnicza Czas, Lublin.

Konstytucja RP. Projekt Polskiego Stronnictwa Ludowego [1990], „Zielony Sztandar”, 22 lipca.

Konstytucja Rzeczypospolitej Polskiej z dnia 2 kwietnia 1997 r., Dz.U., nr 78, poz. 483, z późn. zm., http://www.sejm.gov.pl/prawo/konst/polski/kon1.htm (dostęp: 25.10.2013).

Nie interesuje nas egoistyczny system wartości. Skrót przemówienia A. Domagalskiego, przewodniczacego Rady Naczelnej PSL [1998], „Zielony Sztandar”, 29 listopada.

Pastuszka S.J., Machynia J. [1997], PSL a Konstytucja, Linia Sp. z o.o., Warszawa.

Polskie partie polityczne. Charakterystyki, dokumenty [1996], red. K.A. Paszkiewicz, Drukarnia i Oficyna Wydawnicza Hektor, Wrocław.

Program polityczny i społeczno-gospodarczy. Dokumenty Nadzwyczajnego Kongresu PSL [1991], Polskie Stronnictwo Ludowe, Warszawa.

Program społeczno-gospodarczy Polskiego Stronnictwa Ludowego [2001], Polskie Stronnictwo Ludowe, Warszawa.

Program społeczno-gospodarczy PSL. VIII Kongres PSL [2004], http://www.psl.org.pl/ dokumenty (dostęp: 31.12.2011).

ProPOzycje pod sondaże [2010], „Zielony Sztandar”, 21 lutego.

Wierzbowski B. [1990], Jaka demokracja? Jaka Konstytucja?, „Zielony Sztandar”, 3 sierpnia.

Żywia, bronia, gospodarują. Dokumenty programowe PSL [1993], Polskie Stronnictwo Ludowe, Warszawa. 


\section{Ideas from the Political, Economic and Social System of the Polish People's Party in the Years 1989-2011}

The article presents the evolution of the political thought of the Polish People's Party (PSL) after 1989 and up until the parliamentary elections of 2011. The main issues to be tackled are the concept of the state's political system as well as its economic model and social policy. PSL's multiyear traditions and its values, among which family and religious values hold an important place, influence the party's views. The party is active on the legislative and - through the creation of coalition governments - executive levels.

Keywords: Polish People's Party, political thought, the state's political system, economic model, social policy. 